Int. J. Dev. Biol. 48: 981-991 (2004)

doi: $10.1387 / \mathrm{ijdb} .041876 \mathrm{jw}$

\title{
Ocular surface epithelial and stem cell development
}

\author{
J. MARIO WOLOSIN, MURAT T. BUDAK and M.A. MURAT AKINCI \\ Department of Ophthalmology, Mount Sinai School of Medicine, New York, USA
}

\begin{abstract}
Phenotypic features and developmental events involved in the genesis of the limbocorneal and conjunctival epithelia are described. Together, these two epithelia define the ocular surface. They derive from a small cohort of optic vesicle-induced $P A X 6^{+}$head ectodermal cells that remain on the surface following lens vesicle formation by the main $P A X 6^{+}$cell cohort. Both epithelia are stratified, and display wet, non-keratinizing phenotypes. The most significant spatial feature of the limbo-corneal epithelium is the segregation of its supporting stem and early precursor cells to the limbus, the outer vascularized rim separating the cornea from the conjunctiva. These stem cells express ABCG2, a xenobiotic transporter present in stem cells from other organs. ABCG2 transport activity excludes the DNA dye Hoechst 33342, allowing the isolation of the ocular stem cells by flow cytometry, as a unique cohort known as a side 'side population'. Limbal stem cells do not form gap junctions and exist as metabolically isolated entities. Tracking of expression changes in Cx43, the main gap junction protein expressed in both the pre-epithelial ectoderm and in the mature central corneal epithelium, indicates that a limbal stem cell phenotype starts developing very soon after lens vesicle invagination, in advance of the appearance of any recognizable anatomical sub-epithelial limbal feature. Differences in Cx43 expression also reveal the very early nature of the divergence in limbo-corneal and conjunctival lineages. The putative involvement of several early genes, including gradients of PAX6 and differences in expression patterns for members of the $I d$ or $m s h$ gene expression regulators are reviewed.
\end{abstract}

KEY WORDS: ocular surface development, connexin43, stem side population cell, ABCG2

\section{Introduction}

The spatial approach and full apposition of the neural ectoderm-derived optic vesicle to a small strip of outer surface head ectoderm represents the central event in eye development. The earliest recognized ectodermal gene expression change associated with this phenomenon is the delimitation of the homeobox PAXG gene expression, which at an earlier stage occurs through a wide swat of the head ectoderm, to the apposition area. The close range interaction leads to a dramatic, overt elongation in the affected ectodermal cells, establishing the lens placode. The morphologically altered cells invaginate and excise from the outer surface to form the lens vesicle. The cellular excision leaves at the surface a small number of cells that, though lacking the morphological features of the cells of the placode, express PAXG. Head surface ectodermal cells that lack $P A X G$ expression continue through a default differentiation path to establish the epidermis. The small cohort of $\mathrm{PAXG}^{+}$cells follows divergent pathways to become the limbo-corneal (LC) and conjunctival (CNJ) epithelia (Davis and Reed, 1996; Koroma et al., 1997; Nishina et al., 1999). The different ocular surface domains are discernable by about the seventh week of human fetal development (Fig. 1), corresponding to embryonic day $12-13$ in rodents.

The study of lens development has been facilitated by a welldefined morphological chronology and the availability of landmark genes. The knowledge gathered is contributing to the identification of multiple controls genes downstream from the initial PAXG expression event (Grindley et al., 1995; Ashery-Padan et al., 2000; Chauhan et al., 2002). In contrast, events related to lineage determination and domain segregation for the ocular surface epithelia are very poorly defined. This chapter will describe what is known about these processes and lay a conceptual framework for future studies.

\section{Ocular surface epithelial phenotypes}

The ocular surface epithelial lineages share many of the basic features of the epidermal system including, a) a stratified pheno-

Abbreviations used in this paper: ALDH, aldehyde dehydrogenase; CNJ, conjunctival; Cx, connexin; LC, limbo-corneal; SP, side population; SSC, side scatter; TSCK, tissue-specific cytokeratin.

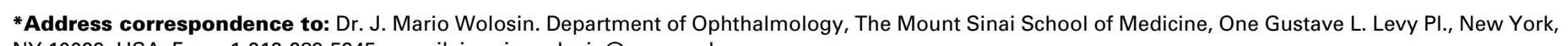
NY 10029, USA. Fax: +1-212-289-5945. e-mail: jmario.wolosin@mssm.edu 
type in which only basal cells retain proliferative capacity and undifferentiated features; b) expression of universal and tissue specific cytokeratin pairs; and c) a rapid renewal plan relying on a reservoir of semi-quiescent stem cells (Wei et al., 1996). Initial differentiation in the epidermis is associated with a switch of cytokeratin expression from the universal stratified epithelial cytokeratin pair, $\mathrm{K} 5$ and $\mathrm{K} 14$, to $\mathrm{K} 1$ and $\mathrm{K} 10$, the tissue specific cytokeratins (TSCKs) of the skin (Moll et al., 1983; Cooper et al., 1985; O'Guin et al., 1987). Similarly, in the ocular surface epithelia there is an equivalent cytokeratin switch from the K5/K14 cytokeratins to their TSCKs, K3 and K12 (Schermer et al., 1986), and K4 (Kurpakus et al., 1994) for the cornea and conjunctiva, respectively. The main phenotypic differences with the epidermis occur in the late differentiation stages. While whereas late differentiation stages in the skin include the synthesis of skin-specific proteins to generate the cornified envelope (keratinization), ocular surface epithelia differentiation involves the acquisition of phenotypic components, apical ion and metabolite transporters, mucin proteins, and tight junctions, components typically found in simple secretory and absorptive epithelia (Wang et al., 1993; Watanabe et al., 1993; Chen et al., 1994; Hamann et al., 1998; Turner et al., 2001). None of these components have so far been identified as being corneal or conjunctival epithelium-specific.

However, it should be stressed that, even though the ocular outer surface phenotypes appear to be quite distinct from those of the epidermis, the actual mechanisms controlling the differences may be determined by a limited number of critical genes. Stratified epithelial keratization is universally and negatively regulated by retinoids. The degree of keratinization in different stratified epithelia primarily reflects their distinct sensitivity to retinoids (Green and Watt, 1982). In this sensitivity hierarchy the ocular surface epithelia, and in particular the conjunctiva, occupy the highest point. The corneal and conjunctival epithelia synthesize or are potentially able to express all the proteins needed for the synthesis of cornified envelopes (Nakamura et al., 2001). However, under normal physiological conditions the levels of circulating and tear retinoids is sufficient to prevent expression of the cross linking activities needed for formation of cornified envelopes. Cornification with devastating consequences does occur though in certain diseases or in newborns subjected to a diet completely devoid of vitamin A
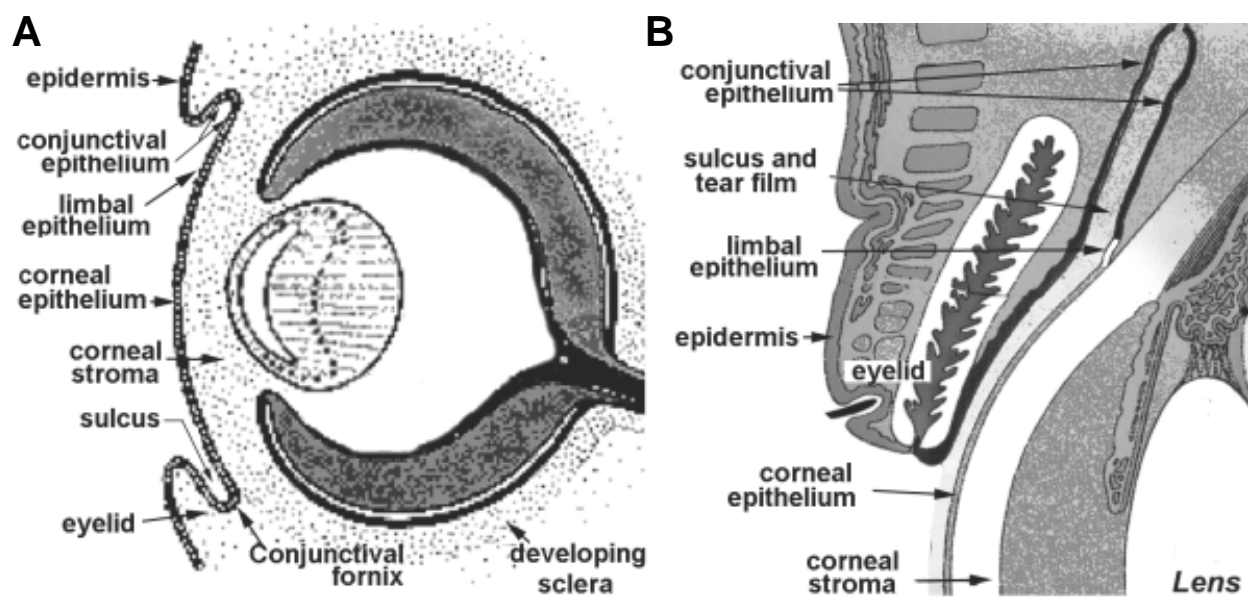

Fig. 1. Schematic description of the ocular surface epithelial zone. (A) The ocular surface at fetal week seven. (B) The adult ocular surface. sources (DeMaeyer, 1986). The mechanisms controlling the cellular retinoid responses associated with the modulation of the stratified epithelial phenotype appear to be highly complex and are poorly understood.

With respect to the comparative analysis of cornea and conjunctiva, a prominent difference is the existence of a single differentiation path in the cornea. The conjunctival precursors can differentiate into either a mosaic type cell similar to the corneal cell, or a mucin secreting goblet cell. Another significant difference relates to the angiogenic properties of the tissues. The avascular nature of the transparent cornea implies that, collectively, its cellular components either do not secrete any angiogenic inducer and/or secrete undetermined angiogenic inhibitors. This is not the case for the conjunctival epithelium; invasion of the corneal surface by conjunctival cells promptly induces neo-vascularization. Presently the molecular basis for the an-angiogenic or anti-angiogenic nature of the corneal epithelium is poorly understood. During epithelial wound healing, when angiogenic processes are greatly stimulated, matrilysin, a metalloproteinase, plays a critical anti-angiogenic role (Kure et al., 2003). Finally, a recent comparative study of global gene expression in the human limbo-corneal and conjunctival epithelia using large Affymetrix ${ }^{\mathrm{TM}}$ oligonucleotide arrays has identified more than 11,000 transcripts in each tissue, representing more than 8,000 unique genes (Turner and Wolosin, manuscript in preparation). Of those, transcripts 256 were present exclusively in the $\mathrm{CNJ}$ and, conversely 181 were present only in the LC system. Thus, the phenotype differences between the two ocular surface epithelia appear to be underpinned by large subsets of genes that are present only in one of the two tissues

\section{Dual domain phenotype in the limbo-corneal epithelium}

In addition to the phenotype features described above, the limbo-corneal epithelium possesses a unique basal cell dual domain arrangement (Wolosin etal., 2000). The stem cells localize exclusively to the basal layer of the outer vascularized limbal rim (Cotsarelis et al., 1989). Using animal chimeras in which the progeny of stem cells can be visually tracked by following $\beta$ galactosidase activity, Collinson et al. (2002) have estimated that the limbo-corneal epithelium in this small rodent is maintained by as little as 100 limbal stem cells. The basal cells of the corneal domain exhibit a more differentiated phenotype, expressing the tissue specific cytokeratins $\mathrm{K} 3$ and $\mathrm{K} 12$ (Schermer et al., 1986). The expression switch from universal (K5/K14) to TSCKs, which in the epidermis and other stratified epithelia occurs with stratification and cessation of proliferation, takes place in the limbo-corneal epithelium along the basal cell plane in sharp manner, as cell transition from limbal to corneal domains (Schermer et al., 1986) and does not involve loss of proliferative capacity. Instead, the cells proliferation rate increases, indicating that this partially differentiated population represents the main transient amplifying (TA) cells for tissue renewal at steady state (Leblond et al., 1959; 
Fig. 2. Connexin43 expression in the human limbocorneal epithelium. Micrographs are negative images of immunofluorescent stainings. (A) Differential interference light micrograph of a frozen section depicting the area of study. In this micrograph the corneal periphery $(\mathrm{CO})$ is located on the left side and the limbus is located to the right. The prominent incursions of the stroma into the plane of the epithelium are the Palisades of Vogt (PV). To include several Palisades in each single section, the frozen tissue was sectioned at an angle oblique to the main limbo-corneal axis. This is indicated by the black line (cutting plane) placed over in an en face light micrograph of the intact limbo-corneal tissue (insert). (B) Immunofluorescence micrograph of $\mathrm{Cx} 43$ distribution in the right framed zone of $A$. The basement membrane (BM) separating epithelial and subepithelial zones is easily identifiable. Connexin staining in the epithelium is extremely sparse and limited to some suprabasalcells. Sub-epithelialendothelial vessels (End.), including those within the Palisades are strongly Cx43positive. (C) Immunofluorescence micrograph of $\mathrm{C} \times 43$ distribution in the left framed (i.e., peripheral corneal) zone of A. Basal and the proximal suprabasal cells are intensively stained. The strong subepithelial stain seen in the limbal zone is absent.
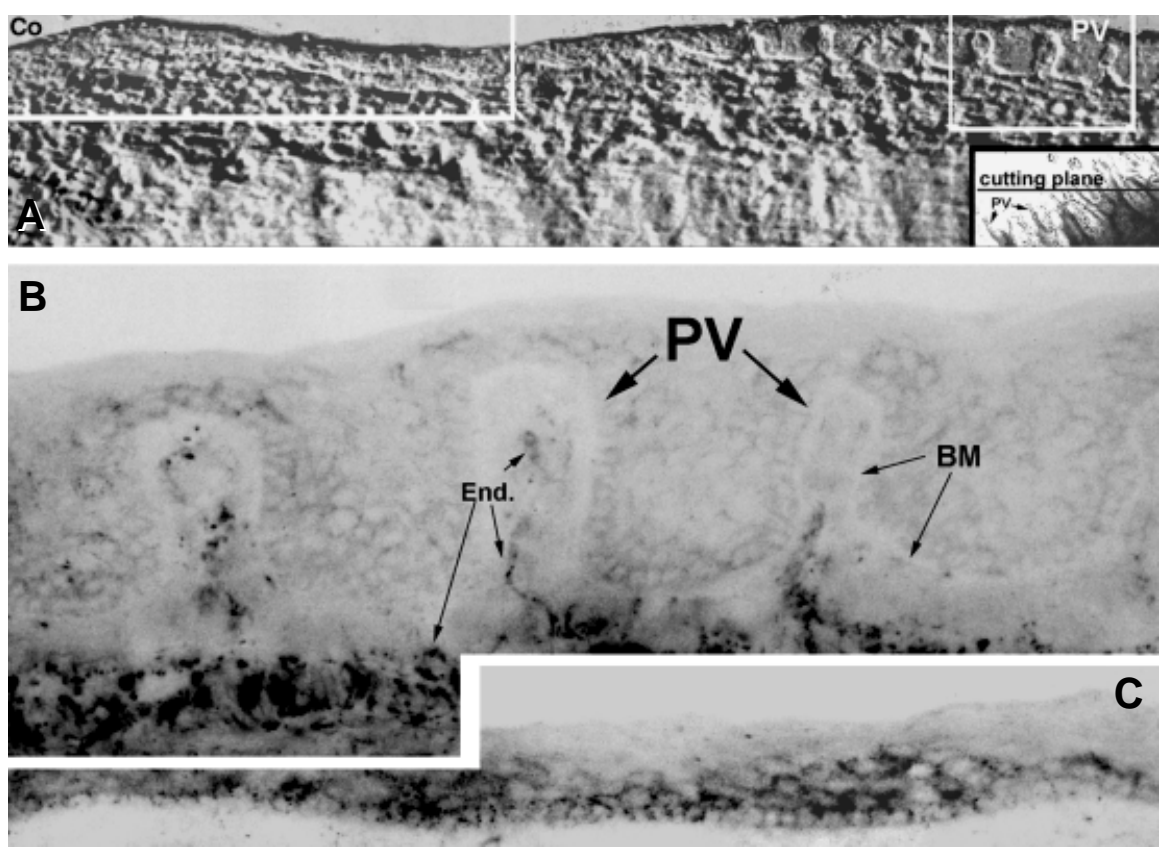

Cotsarelis et al., 1989; Lavker et al., 1991). This transition is associated with several other phenotypic switches, including de novo expression of at least one sialyltransferase (Wolosin and Wang, 1995) and a major increase in connexin43 gap junctions (Matic et al., 1997). When the adult tissue is at steady state, the enzyme $\alpha$-enolase is present almost exclusively within the limbal basal cells (Zieske etal., 1992). The cornea and limbus display also distinct patterns of integrin expression (Stepp et al., 1995). The corneal zone expresses a dramatic accumulation of large quantities of globular metabolic enzyme, in particular aldehyde dehydrogenases and transketolase (Abedinia et al., 1990; Sax et al., 1996; Jester et al., 1999). The expression of these enzymes may relate to transparency and refractive properties, though puzzlingly, the ALDH null mice have so far shown no phenotype (Ness et al., 2002). In the rabbit, the copious expression of the ALDH class 1 (Hough and Piatigorsky, 2003) is limited to the corneal domain (Wolosin, unpublished). The magnitude of the changes in the phenotype at the limbo-corneal demarcation is also suggested by the differences in shape, size and intracellular complexity in the basal cells of both domains in rodents and in the human (Romano et al., 2003). Corneal basal cells are substantially larger than their limbal counterparts. The accumulation of large amount of globular proteins in them maybe a major contributor to this difference.

Functionally, the limbal epithelium displays a lower rate of proliferation than the corneal domain (Cotsarelis et al., 1989). This may indicate that the slow cycling phenotype may extend beyond the bona fide stem cells and include some or many of the early progenitors. The presence of a high density of TGF- $\beta$ receptors in this domain is consistent and may mediate such slower proliferative rate (Joyce and Zieske, 1997).

One of the most consistent features of the limbo-corneal phenotypic dichotomy is the difference in expression of gap junctions. These junctions are large aggregates or plaques of intercellular channels formed by the connexin (Cx) family of proteins. The gap junction channels allow diffusion of ions, low molecular weight metabolites and second messengers between cells and thus, determine the extent of cell metabolic synchrony or cooperation within a population. The corneal epithelium expresses multiple gap junction proteins. $\mathrm{C} \times 26, \mathrm{C} \times 30$ and $\mathrm{C} \times 43$ gap junctions have been confirmed at the protein level by immuno-histology in the human, rat and rabbit (Dong et al., 1994, Matic et al., 1997; Ratkay-Traub et al., 2000; Richard et al., 2002). The presence of Cx50 has also been reported (Dong et al., 1994; Matic et al., 1997). However immunostainings in Cx50 'knockout' mice has demonstrated that the monoclonal antibody that was used in the corneal studies, while showing great selectivity towards $\mathrm{C} \times 50$ in the lens, generates false positives in other ocular tissues, including the corneal epithelium (White at al, 2001). We have confirmed the absence of Cx50 expression at the gene level in the human cornea by both microarray analysis and real time quantitative PCR (Wolosin, unpublished).

The most visible and studied corneal gap junctions are those made of connexin43. Whereas the basal cells of the corneal zone contain numerous large $\mathrm{Cx} 43$ gap junctional plaques and possess excellent cell-cell transmissibility of metabolites and ions, $\mathrm{Cx} 43$ gap junctions are either absent from, or poorly expressed in the limbal basal cells (Fig. 2). In addition the limbal cells show no substantial transmissibility of metabolite tracers, indicating the absence of other functional Cxs in this domain. We have proposed that the paucity of gap junctions in the limbal basal cell is reflective of a gap junctionnegative phenotype of the epithelial stem cells, a feature that may also apply to other epithelial stem cells (Matic et al., 1997; Wolosin et al., 2000). Fittingly, in the human the lowest level of expression occurs in the recedes of the Palisades of Vogt (Fig. 2), the site assumed to harbor the highest concentration of limbal stem cells (Townsend, 1991; Dua and Azuara-Blanco, 2000). In the mature bovine epithelium, the distribution of $\mathrm{K} 12$ and $\mathrm{C} \times 43$ expression identifies two distinct limbal zones. Distal to the cornea, basal and suprabasal cells are $\mathrm{K} 12$ and $\mathrm{C} \times 43$ negative. In the proximal zone, $\mathrm{K} 12$ and $\mathrm{C} \times 43$ are expressed in suprabasal cells. This concurrence of expression is one of a series of observations related to $\mathrm{Cx} 43 / \mathrm{TSCK}$ 


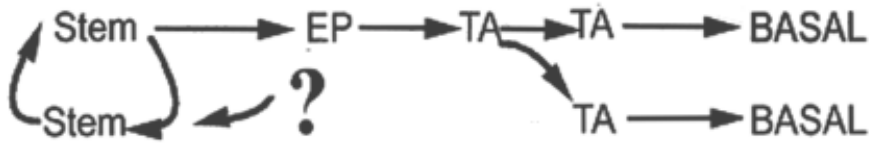

LIMBUS CORNEA
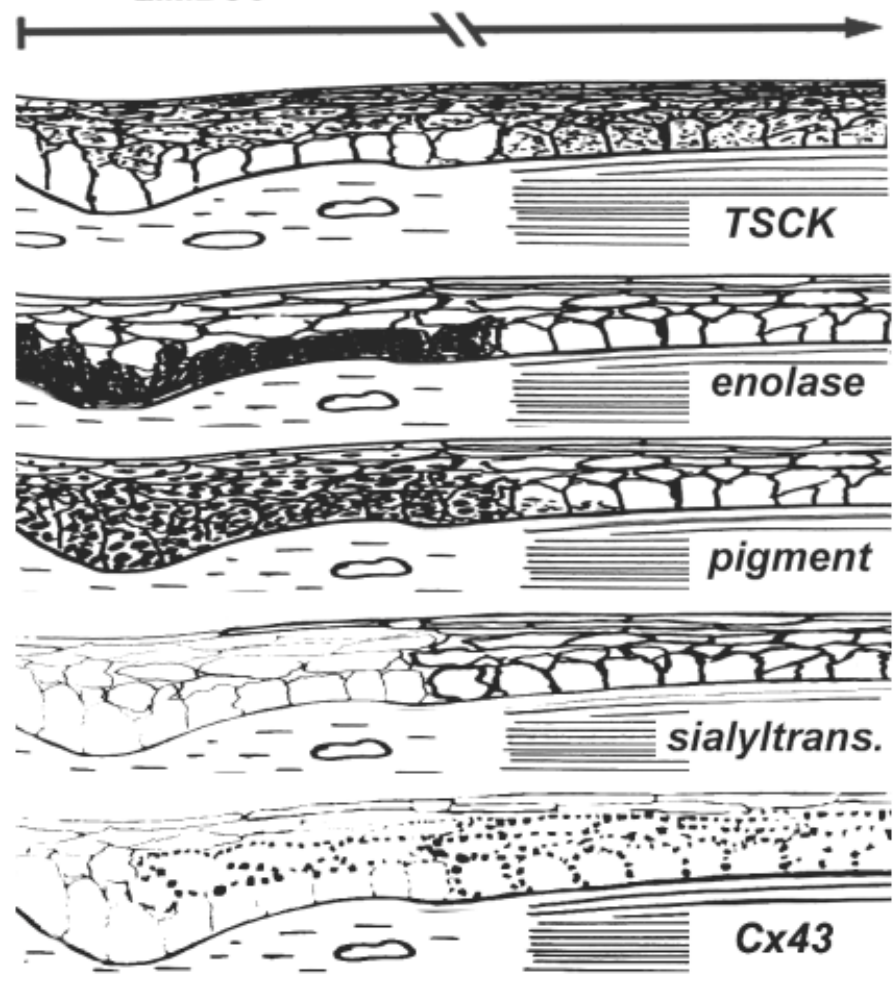

Fig. 3. Summary of some of the functional and expression features of the limbo-corneal epithelium. The upper frame describes the growth and differentiation plan. The basal cell layer of the limbal zone contains the stem cells and their early progenitors (EP). The return arrow and question mark have been introduced to indicate the possibility that some of these precursors could, given the proper environment, revert to a full stem cell phenotype. At he limbo-corneal demarcation, in unison with the transition to a distinct avascular environment there is a sharp differentiation change into the more differentiated but rapidly proliferating transient amplifying (TA) cells. The lower frames describe some known phenotypic transitions taking place at the limbo-corneal demarcation. (TSCK) The basal layer of the limbal epithelium does not express TSCKs, as indicated by the stain-free cytosol. TSCK expression begins at the limbo-corneal demarcation within the basal cell layer or, within the limbus, upon stratification. (Enolase) Under stationary conditions $\alpha$-enolase is preferentially expressed in the cytosol of the limbal basal cells. (Pigment) In many pigmented species, the limbal basal cells acquire heavy pigmentation, most likely due to pigment granule transfer from melanocytes. (Glycosylation) In rabbit, cell membrane O-glycan linked $\alpha-2,3$ sialylation (indicated by the darkness of the membrane traces), is limited to the cornea. This change is due to the de novo expression of a $\alpha-2,3$ sialylyltransferase within the basal cell compartment at the limbo-corneal demarcation. It coincides with the de novo expression of TSCKs. Unlike the case for the TSCK's this sialylation does not occur during intralimbal stratification. (Cx43) The limbal zone shows very little Cx43. In some cases the expression is present in the first layer of supra-basal cells. The density of $\mathrm{Cx} 43$ gap junctions and the size of individual plaques sharply increase at the limbo-corneal demarcation. expression pointing to a causal link between $\mathrm{C} x 43$ expression and initial differentiation (Wolosin, 2000). Several of the features described in this section are graphically exemplified in Fig. 3.

To identify further differences between the limbal and corneal cells we have recently implemented a RT-PCR differential gene display comparing expression in rabbit corneal and limbal basal cells. Our differential gene display protocol yielded over fifty gene sequences showing preferential limbal over-expression. Gene over-expression was reconfirmed by real time PCR. Blast analysis of the reconfirmed sequences identified 29 orthologues of known mammalian genes. Table 1 displays the most interesting of the identified genes, along with limbal/corneal gene expression ratios, accession numbers and ascribed functions. Their involvement in anti-apoptotic and cell growth activities raises the possibility that they may play a role in the limbal stem cell.

\section{The limbal stem cell}

The confinement of the corneal epithelial stem cell to the vascularized limbal rim has serious health consequences. Pathological, environmental or developmental conditions that result in full or partial loss of limbal tissue are associated with a set of clinical syndromes of distinct severity encompassing conjunctival epithelial colonization, neovascularization, and corneal edema, inflammation and opacity. These conditions reflect the depletion of the stem cell reservoir needed for long-term replenishment of the epithelial population (Tsai et al., 1990; Huang and Tseng, 1991). The development of the concept of stem cell segregation in the LC epithelium has led to rapid advances in the clinical application of limbal transplantation for the treatment of limbal deficiencies (Pellegrini etal, 1996; Tsubota etal, 1996).

Naturally, there is a strong interest in the study of this stem cell and the overall homeostatic mechanisms that foster its survival within the limbal zone. One critical factor for progress in this area is the ability to isolate viable stem cells. Stem cells are identified by their unique slow cycling behavior. This feature is demonstrated by a cell's ability to preserve radiolabeled thymidine molecules that were incorporated into its DNA during a prior round of proliferation. Stemness can also be inferred in a number of ways from cell culture tests. Stem cells can be expected to yield a much larger number of cell doublings (i.e., the generational capacity) than TA cells prior to senescence. Another test relies on the ability of stem cells and the less differentiated TA progeny to proliferate from an isolated state (clonogenic growth; Barrandon and Green, 1987). Stem cell-derived clones can continue to proliferate for many generations to form large (>1 cm diameter; 20 cell doublings), compact colonies and even yield new clones upon dissociation and reseeding. TA cells also yield colonies, but owing to their limited proliferative potential, growth in these colonies will stop after a relatively small number of divisions. These tests demonstrate the presence of stem cells but they do not provide ways to characterize the cell. The development of surface markers for stem cells in the hematopoietic system (Civin, 1992; Silvestri et al., 1992) has fostered extraordinary advances in both stem cell basic sciences and clinical practice in hematology. More recently, markers for some neural stem cells have also been identified (Uchida et al., 2000). However, the search for equivalent markers in epithelial systems has been met with very limited success.

Recent developments are likely to overcome the limitations imposed by the absence of surface markers. For several years a 
subpopulation of blood stem cells have been isolated by flow cytometry based on their ability to efficiently efflux the fluorescent DNA binding dye Hoechst 33342 (Goodell et al., 1996). In dilute solution, under excitation with UV light, Hoechst emits blue fluorescence but DNA-bound Hoechst exhibits a strong concentrationdependent, large bathochromic shift; the higher its concentration in the nuclei, the larger the transference of fluorescent light from the blue to the red spectral zone. The high efficiency of efflux in the stem cells implies that, under proper conditions of incubation, these cells will accumulate much less dye than the rest of the cells in the population so that in blue/red flow cytometer emission plots these cells appear as a distinguishable cohort positioned to the (blue) side of the main blue/red cell spot. They have been named side population (SP) cells. Recently, the ATP Binding Cassette subtype G2 (ABCG2), has been proven to be over expressed in these SP cells and to be the source of the efficient Hoechst efflux (Zhou et al., 2001). In addition, ABCG2 and SP properties have been associated with presumptive stem cells in many lineages, including, neurons (Murayama et al., 2002), muscle (Zhou etal., 2001) and epithelia (Summer etal., 2003). These findings suggest that the SP phenotype may be a ubiquitous feature of stem cells.

We have analyzed the presence of SP cells in enzymatically dissociated limbo-corneal cell populations (Fig. 4A; Wolosin et al., unpublished). In the human limbus approximately 2,500 cells/tissue $(0.5 \%$ of a total of 500,000 cells derived from a $\sim 1.5 \mathrm{~mm}$ wide tissue rim comprising both the limbus and some corneal periphery) belonged to the side population. Considering the differences in eye size, the 2,500 figure for the human seem to be generally consistent with the 100 cells estimate obtained by Collison etal. (2002) in the mouse. The majority of the SP was abolished by fumitremorgin $\mathrm{C}$, an ABCG2-specific inhibitor (Robey et al., 2001), confirming that this ocular SP phenotype reflects primarily the activity of this transporter.

The limbal SP cells exhibited unique physical properties. In unison with the fluorescence measurements, the flow cytometer acquires the side (SSC) and forward light scattering properties of each cell. For reasons related to the dependence of light scattering angle to particle size, the SSC reflects the cytosolic complexity of the cells, typically referred to as cell 'granularity'. Our analysis showed that $60-80 \%$ of the limbal SP cells belonged to a cohort of cells displaying the lowest SSC of all the cells. In other words, the SP cells are devoid of intracellular complexity, a feature consistent with the undifferentiated nature of stem cells. Full demonstration of the stem cell nature of the SP cells, will require further tests of their in vivocycling features and

TABLE 1

\section{SURVIVAL AND DEVELOPMENTAL GENES DIFFERENTIALLY} EXPRESSED IN THE LIMBUS

\begin{tabular}{lll} 
Gene $_{\text {Access \# }}$ & $\mathrm{R}_{\mathrm{Li} / \mathrm{Co}}$ & Annotation \\
\hline IAP2 $_{\text {NM_021752 }}$ & 42.4 & $\begin{array}{l}\text { Member of the survivin family. Binds and blocks } \\
\text { caspases. Inhibits apoptosis. }\end{array}$ \\
PIM $_{\text {NM_002648 }}$ & 8.80 & $\begin{array}{l}\text { Ser/Thre kinase of the JAK-STAT pathway. Synergy } \\
\text { with C Myc in proliferation and anti-apoptotic activity. }\end{array}$ \\
SIRP- $\alpha_{\text {M_080792 }}$ & 35.5 & $\begin{array}{l}\text { Trans-membrane multifunctional protein. } \\
\text { Scaffold for multiple regulatory proteins. }\end{array}$ \\
Smarcf1 & 15.4 & $\begin{array}{l}\text { Regulatory component of the SWI/SNF nuclear } \\
\text { protein complex. Global gene expression activity. }\end{array}$ \\
\hline
\end{tabular}

$R$ values represent the average of 5-7 independent experiments. Each $R$ value was calculated from the limbal and corneal $C_{t}$ values. All $C_{t}$ were measure in triplicate in each experiment and were normalized using the geometrical average of the $C_{t}$ for G3PDH and $\beta$-actin. clonogenic properties. In contrast to the limbus, no SP or low SSC cells were found in the stem cell-free corneal zone. We have also examined the expression of ABCG2 in the ocular surface epithelia. Immunostaining confirmed the presence of ABCG2-positive cells in limbus but not in the cornea (Fig. 4 B-D). In the limbal zone, the highest density of positive cells occurred at the recedes of the Palisades of Vogt, the Cx43-negative zone believed to contain the highest accumulation of limbal stem cells.

A
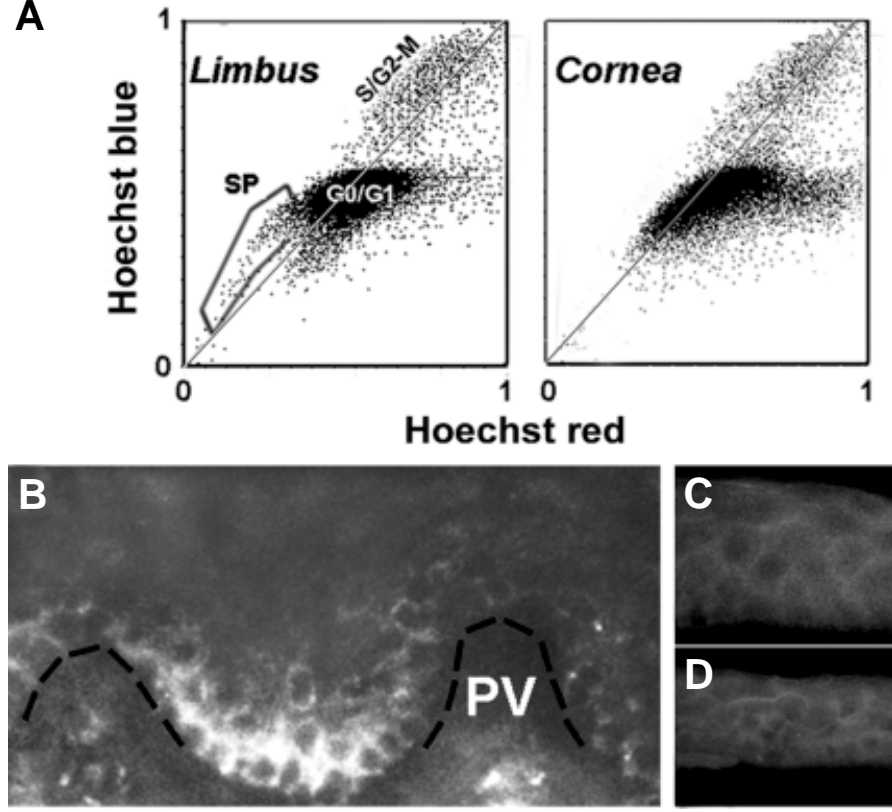

Fig. 4. SP cells and ABCG2 expression in the human limbo-corneal epithelium. Human corneas unsuitable for human transplant were obtained from the National Disease Research Interchange. (A) Flow cytometry blue/red emission dot plots of Hoechst 33342-loaded limbal and corneal human epithelial cells. Single cell suspensions were prepared by sequential digestion with Dispase and trypsin. Cells were incubated in culture medium containing $1.5 \mu \mathrm{g} / \mathrm{ml}$ Hoechst for $90 \mathrm{~min}$ at $37^{\circ} \mathrm{C}$, spun down and resuspended in ice-cold HBSS containing $2 \%$ fetal calf serum and $2 \mu \mathrm{g} / \mathrm{m}$ propidium iodide. The Hoechst-loaded cells were analyzed in a MoFlo flow cytometer equipped with UV and Argon lasers. Blue and red emissions from the UV excitation are used to generate fluorescent emission dot plots. Dead cells, labeled by propidium iodide, have been electronically excluded ("gated out") from these plots. Each dot in a plot represents the relationship between the Hoechst blue and Hoechst red emissions for each live cell. For most cells the blue/red ratio approaches or exceeds the normal ratio (represented by the light gray line). The main spot (GO/G1) gathers most cells containing one copy of DNA. The higher intensity zone (S/G2-M) along the gray line contains all cells with higher DNA content. This includes cells that are actively engaged in DNA synthesis (S) or cells that have completed the DNA duplication process but have not yet undergone or completed the cell division cycle (G2-M). In addition, the limbal population contains a cohort of cells, which both, displays lower blue and red emission intensities, and blue to red ratios that place them to the blue side of the gray line. These cells are known as side population (SP) cells. Note that such cells are not present in the corneal population. (B-D) Indirect immunofluorescence staining of cryosections of limbo corneal tissue for ABCG2. (B) Limbal Palisades of Vogt (PV). A broken black line has been added to indicate the location of the basement membrane. (C) Peripheral corneal zone. (D) Central cornea. 


\section{The conjunctival stem cell}

Since the conjunctiva is a highly vascularized tissue, and the epithelium is quite extensive, its stem cell may be either fully decentralized or located in more than one area. Label retaining experiments performed in rat, mouse and rabbit have led different researchers to advocate, palpebral, fornical and mucocutaneous zones as alternative stem-cell rich locations (Wei et al., 1995; Wirtschafter et al., 1999; Chen et al., 2003).

\section{Developmental expression of ocular surface epithelial genes}

The study of ocular surface epithelial determination and differentiation is dependent on the availability of lineage markers. This became possible following the recognition of the relationship between the distinct stratified lineages and the expression of unique TSCKs (Moll et al., 1983). In the rabbit cornea, ChaloinDufau et al., (1990) detected the initial expression of K12 and K3 on embryonic (E) days 17 and 21, respectively. In mouse, where only K12 is expressed, Kurpakus et al., (1994) identified initial expression of TSCKs on the corneal zone on E15; K4 was initially expressed on E14 on the conjunctival zone overlying the lid bud (Pei and Rodin, 1970). An intriguing question that has not yet been addressed is whether expression of the universal type cytokeratins $\mathrm{K} 5 / \mathrm{K} 14$ precedes the de novo appearance of the TSCKs.

Qin et al., (1997) examined changes in laminin and collagen IV isoforms in mouse, over the same time period. They found that expression of a conjunctival basement membrane laminin protein (alpha2 chain) is first synthesized at about the same time in which keratin K4-positive cells appear. This temporal coincidence may reflect a role for external influences on the differentiation pathways of the conjunctival cells. However, the expression could also reflect a predetermined autonomous epithelial differentiation program. To resolve this issue it will be necessary to determine whether the laminin is secreted by the epithelial cells or by the developing mesenchyme.

More recently, using the gene knockout approach, Yoshida et al., (2000) identified IKB kinase $\alpha$ (Ikk $\alpha$ ) as a major component in the signal transduction leading to the activation of TSCK expression. At birth, the latest viable age of the Ikk $\alpha$-/- mice, only trace amounts of $\mathrm{K} 12$ and $\mathrm{K} 4$ were observed in the cornea and conjunctiva, respectively. Conversely, expression of $\mathrm{K} 5$ was augmented. The physical results are epithelia consisting of multiple layers of basal-like cells in both tissues, rather than the single flattened suprabasal layer typical of this developmental stage. Ikks phosphorylate $\mathrm{I} \mathrm{KB}$, a factor that masks the localization sequence for nuclear binding of NFKB. Fittingly, NFKB is not found in the nuclei in the null mouse, indicating the potential involvement of this ubiquitous transcription regulator in the differentiation. It should be emphasized that these effects are not unique to ocular surface epithelia. They occur also in the epidermis, consistent with the similarities in early differentiation events in all stratified epithelia (Li et al., 1999, Hu et al., 2001).

The study of late stages of ocular surface development has been facilitated by the highly immature nature of this surface in neonate rodents. At birth the eyelids are sealed and the ocular surface epithelium is composed of one basal cell layer and a partial layer of suprabasal cells. Rodent eyelid opening occurs around postnatal day 13 (Wider, 1963). Stratification starts around this time and it is completed over the third week of life. Many other differentiation events occur in the postnatal stage. Corneal glycoconjugates, and/or glycocalyx proteins critical for the protection against pathogen colonization are not present in the neonate (Hazlett and Mathieu, 1989). Expression of gel-forming mucins begins at the fornix seven days after birth and is correlated with the appearance of goblet cells (Watanabe et al., 1993; Tei et al., 1999). Expression of membrane-spanning mucins begins later and correlates to eyelid opening. The concurrent de novoexpression of a sialyltransferase for O-glycans may act as a regulator of this latter development (Uehara et al., 1995). It has been postulated that light may be involved in the coordination of corneal gene expression with eyelid opening. Sax et al., (2000) report that developmentally dependent expression of corneal transketolase is partially inhibited in animals maintained in the dark for the first four weeks of life.

Norman et al., (2004) has recently taken advantage of the postnatal nature of ocular surface development. The corneal epithelial gene complement associated with stratification was identified and quantified using serial analysis of gene expression. Comparison of expression profiles for the corneas of the postnatal day nine (D9) mouse (i.e., somewhat prior to eye opening and the initiation of rapid stratification), and the fully stratified tissue of the adult animal, showed that of the approximately 19,000 identified mRNAs, about one third display higher expression in the D9 and similar fraction do so in the adult tissue. In the authors' words the results provide "new probes for exploring corneal epithelial cell stratification, development, and function and for exploring the intricate relationship between programmed and environmentally induced gene expression in the cornea."

\section{Limbal development}

Since the absence of TSCKs and expression of $\alpha$-enolase act as markers of the stem cell rich basal layer of the limbal zone, these two components have been used to identify the earliest point at which limbal and corneal basal cells become distinguishable. For TSCKs, the initial prenatal expression at the center of the cornea in suprabasal cells expands gradually towards the periphery and into the basal cells during the early post-natal weeks. The expansion stops at the morphologically identifiable limbo-corneal demarcation. Chung et al., (1992) studied $\alpha$-enolase protein expression. For the first 10-11 days after birth, this adult limbal marker is present in all basal cells in the cornea and the limbus. At this point the basal corneal cells are oval shaped. Over the subsequent two weeks, as basal cells at the central cornea change their shape to large and cuboidal and rapid stratification develops, expression of the $\alpha$-enolase protein becomes sequestered to the limbal area.

\section{Cx43 expression and early ocular surface epithelial differentiation}

Overall, the results described in the previous two sections pertain to relatively late stages of the differentiation process. Clearly, there is a substantial temporal gap from the start of the corneo-conjunctival epithelial determination at eye ontogeny 
(approx. on E5 in chicken, E 9.5 in mouse, E10.5 in rat and E11.5 in rabbit) and overt expression of the TSCK markers.

Recently, earlier events in the chronology of ocular surface epithelial development have been revealed by studies of gap junction expression. Since both the pre-ocular embryonic head ectoderm (Ruangvoravat and Lo, 1992) and the adult corneal epithelium are Cx43-positive, we reasoned that the developmental path to the genesis of the $\mathrm{Cx} 43$-negative limbal/stem epithelial cell must include down regulation of expression or assembly of this connexin at some developmental stage. Hence, Cx43 expression was tracked in rat from E 8.5 onwards (Wolosin et al., 2002). At the center of the cornea $\mathrm{Cx} 43$ gap junctions remained visible throughout development, implying that the transition from surface ectoderm to corneal epithelial phenotype occurs without a transition through a Cx43-negative, limbal stem cell-like stage. Figure 5 describes changes occupying prior to the excision of the lens vesicle. The images show that before the lens placode is induced, the outer ectoderm at the future ocular site consists of two layers of round cells expressing a more or less uniform level of well defined $\mathrm{C} \times 43$ gap junctions (Fig. 5A). The first change in ectodermal Cx43 expression or distribution occurs with the formation of the lens placode. The elongated lens precursor express copious amounts of $\mathrm{Cx} 43$ (Fig. 5B). The protein is accumulated in the cell apices rather that at the cell-cell contact zones. The apical connexin accumulation stops abruptly at a non-elongated cell at the margin of the placode. This margin represents the lens vesicle excision point (Fig. 5C).

Figure 6 describes the events that occur after lens vesicle separation. Between E11.5 and E12.5, cells in the ocular surface epithelial zone in maximal proximity to the outer leaflet of the developing retina becomes $\mathrm{C} \times 43$ negative (Fig. $6 \mathrm{~A}-\mathrm{C}$ ). During the subsequent prenatal period the $\mathrm{C} \times 43$-negative zone continues to expand (Fig. 6D). By E19-E20, the location of the Cx43-negative cells conforms to the anatomically identifiable characteristic limbus of the rat and coincides with the K12 negative zone (Wolosin et al., 2002).

Overall, the distribution of $\mathrm{C} \times 43$ gap junctions in the developing ocular surface suggests that underlying phenomena leading to the segregation of the two domains within the limbo-corneal lineages substantially precedes the overt expression of events, which only later on are revealed, or unmasked, by TSCK expression. The
Cx43 developmental pattern is consistent with a model where two interrelated but distinct populations, 'plain' Cx43-positive embryonic CE cells and Cx43-negative embryonic CE stem cells, are present at the ocular rat surface from at least E12.5 onward. Since over time cells migrating from the limbus replace corneal epithelial cells, these embryonic central cornea cells can be seen as a temporary, or tether population. It will be interesting to see whether its gradual replacement by the progeny of the limbal stem cells during the first months of life (Collinson et al., 2002) involves changes in cell phenotype.

In summary, this developmental study shows that a) prior to lens vesicle excision the $\mathrm{Cx} 43$ expression pattern acutely defines the demarcation between future lens epithelium and future corneal epithelium (Fig. 5), and b) following the excision, the expression levels define four head surface domains (Fig. 6). As described, the corneal zone over the developing lens displayed moderate levels of $\mathrm{Cx} 43$ and was ringed by the $\mathrm{Cx} 43^{-}$precursors of the limbus. Beyond these cells (i.e., at the presumptive conjunctival epithelium), expression started again but at a frequency or strength substantially lower than that of the corneal zone. All three zones at this point consisted of roundly shaped cells. The presumptive conjunctiva ended at a stratified zone, expressing higher levels of Cx43, consistent with developing epidermis. A schematic summary of these events is provided in Fig. 7.

\section{What regulates the earliest stages of ocular surface epithelial development?}

As suggested by the early divergence in Cx43 expression levels, critical inductive events in the development of corneal and conjunctival lineages and limbal and corneal segregation may occur far in advance of the expression of overt morphological or protein markers. There is currently little information on the factors that may drive or mediate this event(s).

The first element to consider for lineage determination events is $P A X 6$, the master gene for oculogenesis. Beyond the initial effect on lineage determination, this gene plays critical roles in the mature tissue (Sivak et al., 2004). In humans, heterozygous loss of PAX6 function results in a number of multiple ocular developmental defects, the main one of which is aniridia, the absence of iris. The corneal epithelium of the human aniridic eye displays marked

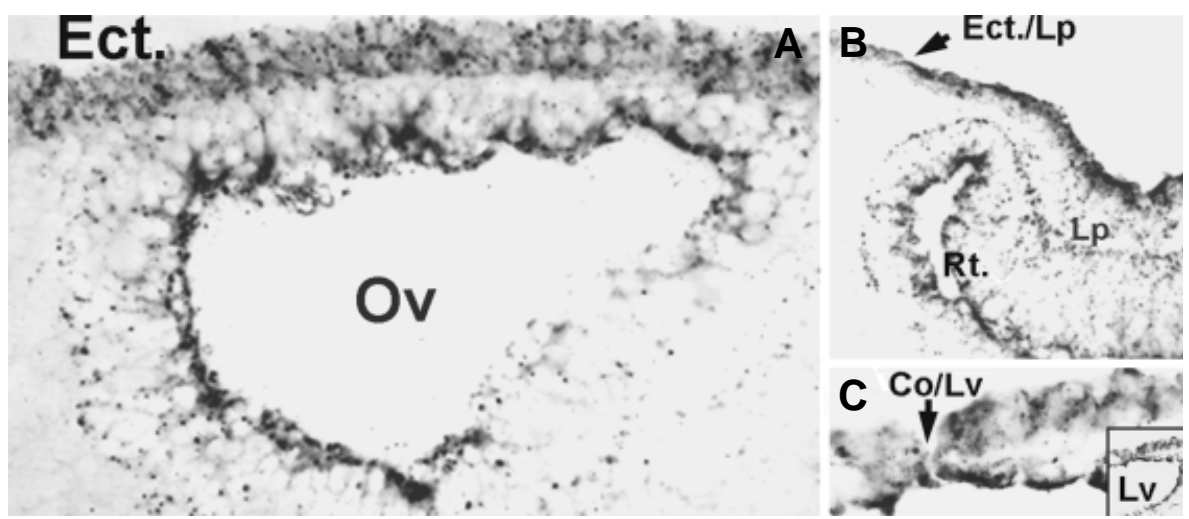

Fig. 5. Cx43 immunostaining in the head ectoderm during early stage of oculogenesis. Micrographs are negative images of immunofluorescent stainings. (A) Section of the E9.5 rat head. The optic vesicle (Ov) has approached the head ectoderm (Ect.) and has flattened against it. Note that the ectoderm is composed of two layers of uniformly Cx43-positive round cells. (B) An E10.5 sample showing the changes in $\mathrm{C} \times 43$ expression during formation of the lens placode. Cx43 increases dramatically in the elongating lens placode cells and concentrates in the apical surface The distribution of $\mathrm{C} \times 43$ seems to define the demarcation between ectodermal and induced placodal cell (Ect. /Lp). The developing retina (Rt.) is indicated. (C) The distribution of $\mathrm{C} x 43$ during lens vesicle (Lv) excision from the surface ectoderm. Note the difference in $C \times 43$ expression between the outer most cell of the excising lens vesicle, and the adjacent cell, that will not undergo excision, i.e, the future corneal epithelial cell. The insert shows a larger zone of the same micrograph. 

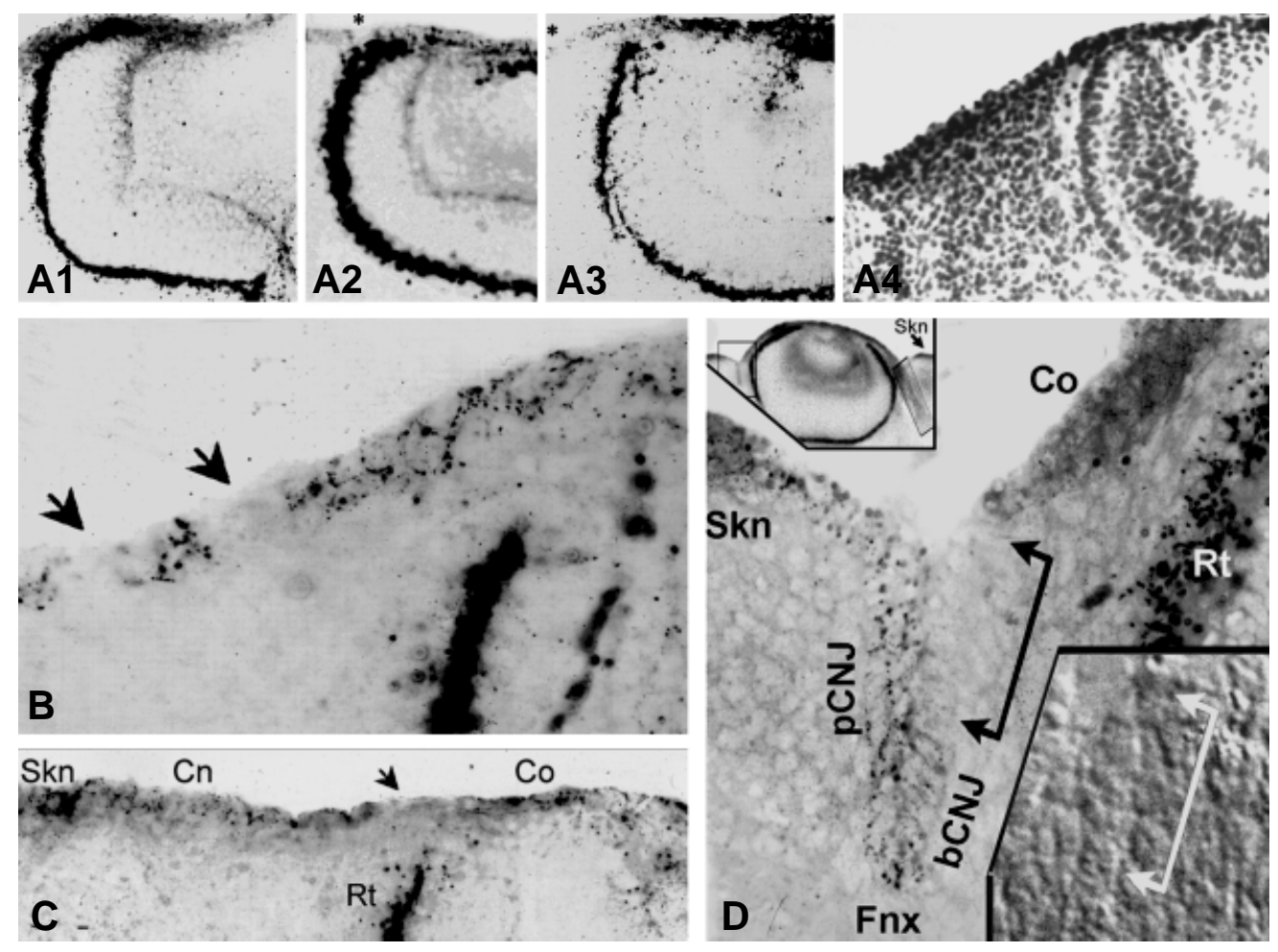

Fig. 6. Cx43 immunostaining of the developing rat ocular surface of the eye following lens formation. Unless stated otherwise micrographs are negative images of immunofluorescent stainings. (AC) Images from E11.5-12.5 stages. As development progresses the tip of the retina (Rt.) becomes in very close apposition to the outer ectodermal zone lying just outside the ectoderm overlying the lens vesicle. (A1-A3; A4 is a positive light micrograph of the A3: after capturing the A3 image the glass slide was dismounted, the section was fixed in formalin and staining with H\&EA). Careful examination of the ectodermal zone near the tip of the retina shows the presence of single $\mathrm{C} \times 43$ cells lasterisks in A2 and A3 and arrowheads on $B$ and $C$ ). In a move away from the developing eye along the ectodermal surface, one finds sequentially a cell monolayer expressing a low level of Cx43puncta, ending in a multilayered epithelium. Based on the developmental features observed in the subsequent stages, the presumptive corneal (Co), conjunctival (Cnj) and epidermal (Skn) domains are indicated in C. The embryonic retina expresses large amounts of $\mathrm{C} \times 43$. (D) $\mathrm{C} \times 43$ immunostaining in an E14.5 eye. The upper insert is a thumbnail of Cx43 immunofluorescent for the whole eye. At this stage, the eye is fully formed and protrudes upwards. Hairpin-shaped folds (framed areas) herald the ontogeny of the conjunctival sac (sulcus). The eyelids will start forming within the next 48-72 hr. Beyond the hairpin loops the surface epithelia thickens and shows higher Cx43 levels, consistent with the skin (Skn) phenotype. The main frame is a high-resolution micrographs of the area highlighted by the left frames in the thumbnail. A journey-like examination of the outer epithelial layer-starting from the $\mathrm{C} \times 43^{+}$epithelium of the cornea (Co)-reveals a substantial $\mathrm{C} \times 43$ zone, which begins just ahead of, and continues half way into, the bulbar side of the hairpin (segment indicated by the linked arrows). Deeper within the hairpin, still on the bulbar side, the epithelium again becomes $C \times 43^{+}$. The stain occurs in discreet puncta. This expression pattern continues uninterruptedly throughout the bottom of the fold and the contra lateral side of the hairpin until the juncture with the skin (Skn). Based on Cx43 expression levels within the sulcus, the respective areas are identified as the early limbal (Li), and bulbar (bCnj), fornical (Fnx) and palpebral (pCnj) conjunctival domains. The lower inserts is a Nomarski-interference micrograph of the stained area showing the physical integrity of the Cx43-negative epithelial cells

functional abnormalities consistent with a deficiency in the number or functional capacity of the limbal stem cell (Puangsricharern and Tseng, 1995; Dua et al., 2000). Limbal stem cell deficiency is further indicated by the prompt recurrence of epithelial pathology following standard corneal transplants in aniridic patients (Gomes et al., 1996) as well as the relative success of heterogeneic limbal transplantation in restoring corneal epithelial function, immune complications notwithstanding. In mouse, rather than aniridia the main phenotype of $P A X 6^{+/-}$heterozygocity is microphthalmia, probably as a result of impaired lens growth. The corneal epithelium of these animals exhibits a decrease in the expression of adherence proteins and keratin $\mathrm{K} 12$ and shows conjunctival invasion consistent with limbal cell deficiency (Davis et al., 2003; Ramaesh et al., 2003). Finally, in $P A X 6^{+/+} / P A X 6^{-1}$ mouse chimeras, $P A X 6^{-1}$ cells are fully excluded from the corneal epithelium, pointing to the acute dependence of the phenotype on $P A X G$ expression (Collinson et al., 2003). It is conceivable that gradients of $P A X 6$, or of some of the identified optic vesicle-induced genes associated with placode development (Xu et al., 1997; Kamachi, 1998), influence the cells at the edge of the placodal zone and thereby activate limited subsets of downstream genes to determine the distinct ocular surface domains.
The second element consists of regulators of gene expression that can be identified in the ectoderm overlying the early lens vesicle. In particular, any such a regulator that is either expressed only after placodal development, or, if having been expressed in the early head ectoderm, is then excluded from the placode. Two such gene families may fulfill these criteria. The first family can be derived from a close look at figures in articles dealing with the muscle segregation homeobox ( $m s h$ ) gene, MsX-2/Hox 8.1(FoerstPotts and Sadler, 1997), indicate that in the E10 mouse, Msx-2, is expressed in the presumptive limbo-corneal epithelium but not in the forming lens (Monaghan etal., 1991; Wu etal., 2003). Lincecum et al., (1998) have shown that mixed cell lines expressing MsX-1 or Msx-2 differentially sort the cells on the basis of $m s h$ isoform expression and that this segregation is mediated by control of cadherin-mediated cell-cell adhesions. The Msx-1 isoform is also expressed in the ectodermal cells (Monaghan et al., 1991). Thus, the expression of msh genes in the early ocular surface could be related to the establishment or segregation of the limbal and conjunctival domains. A second intriguing gene family is the inhibitor of DNA (/d) family. Id s are Helix-Loop-Helix (HLH) proteins, which negatively regulate the activity of differentiationassociated $\mathrm{HLH}$ transcription factors. They are expressed during 
TABLE 2

SIGNAL INTENSITY IN THE AFFYMETRIX HU 133A HUMAN OLIGONUCLEOTIDE ARRAY IN OCULAR SURFACE EPITHELIA FOR THE MRNAS OF THE $\beta$-ACTIN, PAX6, ID AND MSH GENES

Signal intensity

Gene name Limbo-corneal epithelium Conjunctival epithelium

$\begin{array}{lcc}\beta \text {-actin } & 7,008 & 5,699 \\ \text { Pax6 } & 5,469 & 3,611 \\ \text { Id1 } & 6,334 & 1,720 \\ \text { Id2 } & 49 & 37 \\ \text { Id3 } & 235 & \text { absent } \\ \text { Id4 } & 46 & \text { absent } \\ \text { Msx-1 } & \text { absent } & \text { absent } \\ \text { Msx-2 } & 110 & \text { absent }\end{array}$

Note the extraordinary high levels of PAX6 and Id1 in the LC system.

embryonic development and are important for the regulation of cell phenotypes in adults. Kee and Bronner-Fraser (2001) identified a patch of /d type $4(/ d 4)$-positive ectodermal cells on the head ectoderm of the E2 chick (developmental stage 14). In the whole embryo mount, the patch appears as a rim encircling the developing ectoderm/neural apposition zone, i.e, before placodal development. On E3, following invagination of the placodal cells, Id4 expression is present on the presumptive ocular surface epithelium overlying an /d4-negative lens vesicle and embryonic retina. The micrographs presented in the msh and Id expression studies suggest gene levels for the Msx-2 and $/ d 4$ isoforms are at its highest in the zone overlying the tip of the developing retina, i.e., in the area that will become either the limbus or the conjunctiva, or both.

An Affymetrix oligonucleotide microarray study of gene expression in the adult human LC and CNJ epithelia provides relevant information on this latter point (Table 2; Turner and Wolosin, unpublished). Consistent with previous studies, PAX 6 is expressed at very high levels in both LC and CNJ. The level of

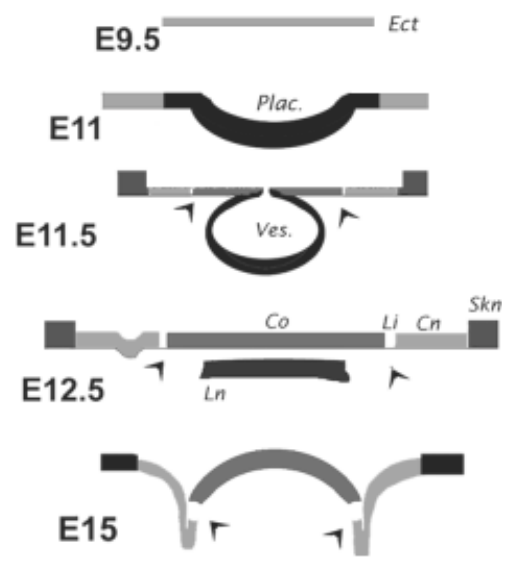

Fig. 7. Schematic representation of the fate of cells derived from the ectoderm between E9 and E15 in terms of Cx43 expression levels. Levels are represented by degrees of darkness. The ectodermal (Ect), corneal (Co), limbal (Li) and conjunctival (Cn) domains of the ocular surface, in addition to the skin (Skn) and lens (Ln) are indicated. Arrowheads point to a (putative) fixed location throughout development. expression is somewhat higher in the LC, a difference that, at least superficially, is consistent with the gradient hypothesis formulated above regarding $P A X 6$. However, it is with respect to the Msx-2 and Idgenes, that the LC/CNJ differences are truly pronounced. We found that Msx-2 is expressed only in the LC system and that Msx-1 is not expressed in either tissue. With respect to $/ d$ genes, $/ d 1$, Id3 and /d4 display a marked LC to CNJ differential expression pattern. Overall, the expression patterns for $M s x-2$ and $/ d$ genes in the adult human support the notion that these two gene families may be involved in domain segregation and determination and/or phenotype maintenance of the distinct lineages. In addition, $/ d 1$ is expressed at such high levels (see Table 2) in the LC, that a critical role for this gene on adult corneal function is likely. It will be interesting to see how $P A X 6$ and these two additional genes distribute in the LC between limbal and corneal domains.

Finally, as inferred from the studies of $\mathrm{Cx} 43$ down regulation (Fig. 6), the potential involvement of the embryonic retina as an inductive influence needs to be taken into account.

\section{Acknowledgements}

Supported by PHS Grants EY 07773, EY015132 and EY 01867 and by an Unrestricted grant to the Department of Ophthalmology from Research to Prevent Blindness, Inc. JMW is recipient of an RPB Senior Scientific Investigator Award.

\section{References}

ASHERY-PADAN, R. MARQUARDT, T., ZHOU, X. and GRUSS, P. (2002). Pax6 activity in the lens primordium isrequired for lens formation and for correct placement of a single retina in the eye. Genes Dev. 14: 2701-11.

ABEDINIA M., PAIN T., ALGAR E.M. and HOLMES R.S. (1990). Bovine corneal aldehyde dehydrogenase: the major soluble corneal protein with a possible dual protective role for the eye. Exp Eye Res. 51:419-26.

BARRANDON Y., and GREEN H. (1987). Three clonal types of keratinocyte with different capacities for multiplication. ProcNat/ Acad Sci USA; 84:2302-6.

CHALOIN-DUFAU C., SUN T.T., AND DHOUAILLY D. (1990) Appearance of the keratin pair K3/K12 during embryonic and adult corneal epithelial differentiation in the chick and in the rabbit. Cell Differ Dev. 32: 97-108.

CHAUHAN B.K., ZHANG W., CVEKLOVA K., KANTOROW M., and CVEKL A. (2002) Identification of differentially expressed genes in mouse Pax6 heterozygous lenses. Invest Ophthalmol Vis Sci. 43:1884-90

CHEN M., WANG Y., BEGLEY C.G., and WOLOSIN J.M. (1994). Synthesis of rabbit corneal epithelial glycocalyx in vitro. Exp Eye Res. 58:267-76.

CHEN W., ISHIKAWA M., YAMAKI K., and SAKURAGI S. (2003) Wistar rat palpebral conjunctiva contains more slow-cycling stem cells that have larger proliferative capacity: implication for conjunctival epithelial homeostasis. Jpn J Ophthalmol. 47:119-28.

CHUNG E.H., BUKUSOGLU G., and ZIESKE J.D. (1992). Localization of cornea epithelial stem cells in the developing rat. Invest Ophthalmol Vis Sci. 33:2199206.

CIVIN, C.I. (1992). Identification and positive selection of human progenitor/stem cells for bone marrow transplantation. Prog Clin Biol Res. 377:461-72.

COLLINSON J.M., MORRIS L., REID A.I., RAMAESH T., KEIGHREN M.A., FLOCKHART J.H., HILL R.E., TAN S.S., RAMAESH K., DHILLON B., and WEST J.D. (2002). Clonal analysis of patterns of growth, stem cell activity, and cell movement during the development and maintenance of the murine corneal epithelium. Dev Dyn. 224: 432-40.

COLLINSON J.M., QUINN J.C., HILL R.E., and WEST J.D. (2003). The roles of Pax6 in the cornea, retina, and olfactory epithelium of the developing mouse embryo. Dev Biol. 255:303-12.

COOPER D., SCHERMER A., and SUN T.T. (1985). Classification of human epithelia and their neoplasms using monoclonal antibodies to keratins: strategies, applications, and limitations. Lab Invest. 52:243-56 
COTSARELIS G., CHENG S.Z., DONG G., SUN T.T., and LAVKER R.M. (1989). Existence of slow-cycling limbal epithelial basal cells that can be preferentially stimulated to proliferate: implications on epithelial stem cells. Cell. 57:201-9.

DAVIS J., DUNCAN M.K., ROBISON W.G. JR., and PIATIGORSKY J. (2003). Requirement for Pax6 in corneal morphogenesis: a role in adhesion. $J$ Cell Sci. 116:2157-67.

DAVIS J.A., and REED R.R.(1996). Role of Olf-1 and Pax-6 transcription factors in neurodevelopment. J Neurosci. 16:5082-94.

DEMAEYER E.M. (1986). The WHO programme of prevention and control of vitamin A deficiency, xerophthalmia and nutritional blindness. Nutr Health.4:105-12.

DUA H.S., and AZUARA-BLANCO A. (2000). Limbal stem cells of the corneal epithelium. Surv Ophthalmol. 44: 415-25.

DUA H.S., SAINI J.S., AZUARA-BLANCO A., and GUPTA P. (2000). Limbal stem cell deficiency: concept, aetiology, clinical presentation, diagnosis and management. Indian J Ophthalmol. 48:83-92.

DONG Y., ROOS M., GRUIJTERS T., DONALDSON P., BULLIVANT S., BEYER E. and KISTLER J. (1994). Differential expression of two gap junction proteins in corneal epithelium. Eur J Cell Biol. 64:95-100.

FOERST-POTTS L., and SADLER T.W. (1997). Disruption of Msx-1 and Msx-2 reveals roles for these genes in craniofacial, eye, and axial development. Dev Dyn. 09:70-84.

GOMES J.A., EAGLE R.C. JR., GOMES A.K., RAPUANO C.J., COHEN E.J., and LAIBSON P.R. (1996). Recurrent keratopathy after penetrating keratoplasty for aniridia. Cornea. 15:457-62.

GOODELL M.A., BROSE K., PARADIS G., CONNER A.S., and MULLIGAN R.C. (1996). Isolation and functional properties of murine hematopoietic stem cells that are replicating in vivo. J Exp Med. 183:1797-806.

GREEN H., and WATT F.M.(1982). Regulation by vitamin A of envelope cross-linking in cultured keratinocytes derived from different human epithelia. Mol Cell Biol. 2:1115-7.

GRINDLEY J.C., DAVIDSON D.R. and. HIL R.E. (1995). The role of Pax-6in eye and nasal development. Development. 121:1433-42

HAMANN S., ZEUTHEN T., LA COUR M., NAGELHUS E.A., OTTERSEN O.P., AGRE P., and NIELSEN S. (1998). Aquaporins in complex tissues: distribution of aquaporins 1-5 in human and rat eye. Am J Physiol. 274:C1332-45.

HAZLETT L.D., and MATHIEU P. (1989). Glycoconjugates on corneal epithelial surface: effect of neuraminidase treatment. J Histochem Cytochem. 37:1215-24.

HOUGH R.B., and PIATIGORSKY J. (2004). Preferential transcription of rabbit Aldh1a1 in the cornea: implication of hypoxia-related pathways. Mol Cell Biol. $24: 1324-40$

HU Y., BAUD V., OGA T., KIM K.I., YOSHIDA K., and KARIN M. (2001).IKKalpha controls formation of the epidermis independently of NF-kappaB. Nature. 410:710-4.

HUANG, A.J. and TSENG, S.C.(1991). Corneal epithelial wound healing in the absence of limbal epithelium. Invest Ophthalmol Vis Sci32:96-105.

JESTER J.V., MOLLER-PEDERSENT., HUANG J., SAXC.M., KAYSW.T., CAVANGH H.D., PETROLL W.M., and PIATIGORSKY J. (1999). The cellular basis of corneal transparency: evidence for 'corneal crystallins'. J Cell Sci.112:613-22.

JOYCE N.C., and ZIESKE J.D.(1997).Transforming growth factor-beta receptor expression in human cornea. Invest Ophthalmol Vis Sci38:1922-8.

KAMACHI Y., UCHIKAWA M., COLLIGNON,J, LOVELL-BADGE R., and KONDOH $H$. (1998). Involvement of Sox1, 2 and 3 in the early and subsequent molecular events of lens induction. Development. 125:2521-32.

KEE Y., and BRONNER-FRASER M. (2001). Id4 expression and its relationship to other Id genes during avian embryonic development. Mech Dev. 109:341-5.

KOROMA B.M., YANG J.M., and SUNDIN O.H.(1997). The Pax-6 homeobox gene is expressed throughout the corneal and conjunctival epithelia. Invest Ophthalmol Vis Sci. 38:108-20.

KURE T., CHANG J.H., KATO T., HERNANDEZ-QUINTELA E., YE H., LU P.C., MATRISIAN L.M., GATINEL D., SHAPIRO S., GOSHEH F., AZAR D.T., and GOSHEHF. (2003). Corneal neovascularization after excimer keratectomy wounds in matrilysin-deficient mice. Invest Ophthalmol Vis Sci. 44:137-44.

KURPAKUS M.A., MANIACI M.T., and ESCO M. (1994). Expression of keratins K12, K4 and K14 during development of ocular surface epithelium. Curr Eye Res. 13:805-14.
LAVKER R.M., DONG G., CHENG S.Z., KUDOH K., COTSARELIS G., and SUN T.T. (1991). Relative proliferative rates of limbal and corneal epithelia. Implications of corneal epithelial migration, circadian rhythm, and suprabasally located DNA-synthesizing keratinocytes. Invest Ophthalmol Vis Sci. 32:1864-75.

LEBLOND C.P., MESSIER B., and KOPRIWA B.(1959). Thymidine-h3 as a tool for the investigation of the renewal of cell populations. Lab invest. 8:296-306.

LI Q., LU Q., HWANG J.Y., BUSCHER D., LEE K.F., IZPISUA-BELMONTE J.C., and VERMA I.M.(1999). IKK1-deficient mice exhibit abnormal development of skin and skeleton. Genes Dev. 13:1322-8.

LINCECUM J.M., FANNON A., SONG K., WANG Y., and SASSOON D.A. (1998). Msh homeobox genes regulate cadherin-mediated cell adhesion and cell-cell sorting. J Cell Biochem. 70:22-8

MATIC M., PETROV, CHEN. S., WANG C., DIMITRIJEVICH S.D. and WOLOSIN J.M. (1997). Stem cells of the corneal epithelium lack connexins and metabolite transfer capacity. Differentiation. 61: 251-26.

MOLL R., FRANKE W.W., SCHILLER D.L., GEIGER B., and KREPLER R. (1982). The catalog of human cytokeratins: patterns of expression in normal epithelia, tumors and cultured cells. Cell. 31:11-24.

MONAGHAN A.P., DAVIDSON D.R., SIME C., GRAHAM E., BALDOCK R. BHATTACHARYA S.S., and HILL R.E. (1991). The Msh-like homeobox genes define domains in the developing vertebrate eye. Development. 112:1053-61.

MURAYAMA A., MATSUZAKI Y., KAWAGUCHI A., SHIMAZAKI T., and OKANO H.(2002). Flow cytometric analysis of neural stem cells in the developing and adult mouse brain. J Neurosci Res. 69:837-47.

NAKAMURA T., NISHIDA K., DOTA A., MATSUKI M., YAMANISHI K., and KINOSHITA S. (2001). Elevated expression of transglutaminase 1 and keratinization-related proteins in conjunctiva in severe ocular surface disease. Invest Ophthalmol Vis Sci. 42:549-56.

NEES D.W., WAWROUSEK E.F., ROBISON W.G. JR., and PIATIGORSKY J. (2002). Structurally normal corneas in aldehyde dehydrogenase 3a1-deficient mice. Mol Cell Biol. 22:849-55.

NISHINA S., SHINICHIK., YAMAGUCHIY., HANDA H., KAWAKAMI A., FUJISAWA H., and AZUMA N. (1999). PAX6 expression in the developing human eye $\mathrm{Br} J$ Ophthalmo/83:723-27

NORMAN B., DAVIS J., and PIATIGORSKY J. (2004). Postnatal gene expression in the normal mouse cornea by SAGE. Invest Ophthalmol Vis Sci. 45:429-40.

O'GUIN W.M., GALVIN S., SCHERMER A., and SUN T.T. (1987). Patterns of keratin expression define distinct pathways of epithelial development and differentiation. Curr Top Dev Biol. 22:97-125.

PEI Y.F., and RHODIN J.A. (1970). The prenatal development of the mouse eye. Anat Rec. 168:105-25.

PELLEGRINI, G., TRAVERSO, C.E., FRANZI, A.T., ZINGIRIAN, M., CANCEDDA R. and DE LUCA, M. (1996). Long-term restoration of damaged corneal surfaces with autologous cultivated corneal epithelium. Lancet 349:990-3

PUANGSRICHARERN V., and TSENG S.C. (1995). Cytologic evidence of corneal diseases with limbal stem cell deficiency. Ophthalmology. 102:1476-85

QIN P., PIECHOCKI M., LU S., and KURPAKUS M.A. (1997). Localization of basement membrane-associated protein isoforms during development of the ocular surface of mouse eye. Dev Dyn. 209:367-76.

RAMAESH T., COLLINSON J.M., RAMAESHK., KAUFMAN M.H., WEST J.D., and DHILLON B. (2003). Corneal abnormalities in Pax6+/- small eye mice mimic human aniridia-related keratopathy. Invest Ophthalmol Vis Sci. 44:1871-8.

RATKAY-TRAUB I., HOPP B., BOR Z., DUX L., BECKER D.L., and KRENACS T. (2001). Regeneration of rabbit cornea following excimer laser photorefractive keratectomy: a study on gap junctions, epithelial junctions and epidermal growth factor receptor expression in correlation with cell proliferation. Exp Eye Res. 73:291-302.

RICHARD G., ROUANF., WILLOUGHBY C.E., BROWNN., CHUNG P., RYYNANEN M., JABS E.W., BALE S.J., DIGIOVANNA J.J., UITTO J., and RUSSELL L. (2002). Missense mutations in GJB2 encoding connexin-26 cause the ectodermal dysplasia keratitis-ichthyosis-deafness syndrome. Am J Hum Genet. 70:1341-8.

ROBEY R.W., HONJO Y., VAN DE LAAR A., MIYAKE K., REGIS J.T., LITMAN T., and BATES S.E. (2001). A functional assay for detection of the mitoxantrone resistance protein, MXR (ABCG2). Biochim Biophys Acta 1512:171-82. 
ROMANO A.C., ESPANA E.M., YOO S.H., BUDAK M.T., WOLOSIN J.M., and TSENG S.C. (2003). Different cell sizes in human limbal and central corneal basal epithelia measured by confocal microscopy and flow cytometry. Invest Ophthalmol Vis Sci. 44:5125-9

RUANGVORAVAT C.P., and LO C.W. (1992). Connexin 43 expression in the mouse embryo: localization of transcripts within developmentally significant domains. Dev Dyn. 194:261-81.

SAX C.M., KAYS W.T., SALAMON C., CHERVENAK M.M., XU Y.S., and PIATIGORSKY J. (2000). Transketolase gene expression in the cornea is influenced by environmental factors and developmentally controlled events. Cornea. 19:833-41.

SCHERMER A., GALVIN S. and SUN T.T. (1986). Differentiation-related expression of a major $64 \mathrm{~K}$ corneal keratin in vivo and in culture suggests limbal location of corneal epithelial stem cells. J Cell Biol. 103: 49-62.

SILVESTRI, F., BANAVALI, S., BACCARANI, M. and PREISLER, H.D.(1992). The CD34 hemopoietic progenitor cell associated antigen: biology and clinical applications. Haematologica 77:265-73.

SIVAK J.M., WEST-MAYS J.A., YEE A., WILLIAMS T., and FINI M.E. (2004). Transcription Factors Pax6 and AP-2alpha Interact To Coordinate Corneal Epithelial Repair by Controlling Expression of Matrix Metalloproteinase Gelatinase B. Mol Cell Biol. 24:245-57.

STEPP M.A., ZHU L., SHEPPARD D., and CRANFILL R.L (1995).Localized distribution of alpha 9 integrin in the cornea and changes in expression during corneal epithelial cell differentiation. J Histochem Cytochem. 43:353-62.

SUMMER R., KOTTON D.N., SUN X., MA B., FITZSIMMONS K., and FINE A. (2003). SP (Side Population) Cells and Bcrp1 Expression in Lung. Am J Physiol Lung Cell Mol Physiol. 285:L97-L104.

TEI M., MOCCIA R., and GIPSON I.K. (1999). Developmental expression of mucin genes ASGP (rMuc4) and rMuc5ac by the rat ocular surface epithelium. Invest Ophthalmol Vis Sci. 40:1944-51.

TOWNSEND W.M. (1991). The limbal palisades of Vogt. Trans Am Ophthalmol Soc.89:721-56.

TSAI R.J., SUN T.T., and TSENG S.C. (1990). Comparison of limbal and conjunctival autograft transplantation in corneal surface reconstruction in rabbits. Ophthalmology 97:446-55.

TSUBOTA, K., SATAKE, Y., OHYAMA, M., TODA, I., TAKANO, Y., ONO, M., SHINOZAKI, N. and SHIMAZAKI, J. (1996). Surgical reconstruction of the ocular surface in advanced ocular cicatricial pemphigoid and Stevens-Johnson syndrome. Am. J. Ophthalmol. 122: 38-52.

TURNER H.C., ALVAREZ L.J., and CANDIA O.A. (2001). Identification and localization of acid-base transporters in the conjunctival epithelium. Exp Eye Res. 72:519-31.

UCHIDAN., BUCKD.W., HE D., REITSMAM.J., MASEKM., PHANT.V., TSUKAMOTO A.S., GAGE F.H., and WEISSMAN I.L. (2000). Direct isolation of human central nervous system stem cells. Proc Natl Acad Sci USA. 97:14720-5.

UEHARA F., OZAWA M., IWAKIRIN., and OHBAN. (1995). Expression of distribution of alpha 2,3-sialyltransferase mRNA in rat cornea. Jpn J Ophthalmol. 39:30-4
WANG Y., CHEN M., and WOLOSIN J.M. (1993). ZO-1 in corneal epithelium; stratal distribution and synthesis induction by outer cell removal. Exp Eye Res. 57:28392.

WATANABE H., TISDALE A.S., and GIPSON I.K. (1993). Eyelid opening induces expression of a glycocalyx glycoprotein of rat ocular surface epithelium. Invest Ophthalmol Vis Sci. 34:327-38

WEI Z.G, COTSARELIS G., SUN T.T., and LAVKER R.M. (1995). Label-retaining cells are preferentially located in fornical epithelium: implications on conjunctival epithelial homeostasis. Invest Ophthalmol Vis Sci. 36:236-46.

WEI Z.G., SUN T.T., and LAVKER R.M. (1996). Rabbit conjunctival and corneal epithelial cells belong to two separate lineages. Invest Ophthalmol Vis Sci. 37:523-33.

WIDER S. (1963). Effect of hormones on eyelid disjunction in the rat Ophthalmologica. 146:268-74.

WHITE, T.W., SELliTTO, C., PAUL, D.L. and GOODENOUGH, D.A. (2001). Prenatal lens development in connexin43 and connexin50 double knockout mice. Invest. Ophthalmol. Vis. Sci. 42: 2916-23.

WIRTSCHAFTER J.D., KETCHAM J.M., WEINSTOCK R.J., TABESH T., and MCLOON L.K. (1999) Mucocutaneous junction as the major source of replacement palpebral conjunctival epithelial cells. Invest Ophthalmo/ Vis Sci. 40:313846.

WOLOSIN J.M., and WANG Y. (1995). Alpha-2,3 sialylation differentiates the limbal and corneal epithelial cell phenotypes. Invest Ophthalmol Vis Sci. 36:2277-86.

WOLOSIN J.M., XIONG X., SCHUTTE M., STEGMAN Z., and TIENG A. (2000). Stem cells and differentiation stages in the limbo-corneal epithelium. Prog Retin Eye Res. 19:223-55

WOLOSIN J.M., SCHUTTE M., ZIESKE J.D., and BUDAK M.T. (2002). Changes in connexin43 in early ocular surface development. Curr Eye Res. 24:430-8

WU L.Y., LI M., HINTON D.R., GUO L., JIANG S., WANG J.T., ZENG A., XIE J.B., SNEAD M., SHULER C., MAXSONR.E. JR., and LIUY.H. (2003). Microphthalmia resulting from MSX2-induced apoptosis in the optic vesicle. Invest Ophthalmo/ Vis Sci. 44:2404-12.

XU P.X., WOO I., HER H., BEIER D.R., and MAAS R.L. (1997). Mouse Eya homologues of the Drosophila eyes absent gene require Pax6 for expression in lens and nasal placode. Development. 124:219-31.

YOSHIDA K., HU Y.,and KARIN M. (2000). IkappaB kinase alpha is essential for development of the mammalian cornea and conjunctiva. Invest Ophthalmol Vis Sci. 41:3665-9.

ZIESKE J.D., BUKUSOGLU G., and YANKAUCKAS M.A.(1992). Characterization of a potential marker of corneal epithelial stem cells. Invest Ophthalmol Vis Sci. 33:143-52

ZHOU S., SCHUETZ J.D., BUNTING K.D., COLAPIETRO A.M., SAMPATH J., MORRIS J.J., LAGUTINA I., GROSVELD G.C., OSAWA M., NAKAUCHI H., and SORRENTINO B.P. (2001). The ABC transporter Bcrp1/ABCG2 is expressed in a wide variety of stem cells and is a molecular determinant of the sidepopulation phenotype. Nat Med. 7:1028-34 